\title{
TINGKAT KESIAPAN MASYARAKAT JASA KONSTRUKSI DALAM PENERAPAN E-PROCUREMENT DI LHOKSEUMAWE
}

\author{
M. Fauzan ${ }^{1)}$, Mukhlis ${ }^{2)}$, T. Ricky Husny ${ }^{3)}$ \\ 1) 2) Jurusan Teknik Sipil Fakultas Teknik Universitas Malikussaleh \\ fauzanunimal@gmail.com; muuukhlis@gmail.com
}

\begin{abstract}
Abstrak
Kemajuan dalam bidang teknologi komunikasi membawa dampak yang sangat besar bagi kehidupan manusia dalam semua aspek, baik itu dampak yang positif maupun dampak yang negatif. Salah satu aspek yang terkena dampak dengan kemajuan teknologi informasi adalah proses pengadaan barang dan jasa. Pengadaan barang dan jasa secara konvensional membuka dan menimbulkan resiko beberapa hal buruk dalam pengadaan barang dan jasa seperti korupsi, ketidakamanan berkas dan kecurangan-kecurangan lain yang sering terjadi dalam pengadaan barang dan jasa secara konvensional. Karena itulah e-procurement menjadi solusi yang tepat untuk mengatasi masalah-masalah tersebut. Penelitian ini dilakukan dengan tujuan untuk mengetahui seberapa tinggi tingkat kesiapan masyarakat jasa konstruksi apabila pengadaan barang jasa secara elektronik (e-procurement) diterapkan di Lhokseumawe. Dengan hasil yang diperoleh, diharapkan akan menjadi sumbangsih bagi kemajuan dan kesuksesan penerapan e-procurement di Lhokseumawe. Penelitian dilakukan secara studi kepustakaan dan penyebaran kuesioner kepada masyarakat jasa konstruksi yang menjadi responden. Setelah kuesioner diisi oleh responden yang dimaksud maka penulis melakukan analisis kuesioner untuk mencari reliabilitas dan validitas kuesioner. Setelah dilakukan analisis didapatkan nilai reliabilitas sebesar 0,862 , dan nilai tersebut menunjukan bahwa kuesioner yang digunakan reliabel. Dalam analisis validitas, terdapat 4 butir pertanyaan yang dianggap tidak valid karena nilai korelasi dengan $r$-tabel kurang dari 0,361. Dilihat dari jawaban masing-masing kuesioner, umumnya mereka mendukung dan siap untuk menerapkan e-procurement di Lhokseumawe. Secara kolektif dapat dikatakan bahwa tingkat kesiapan masyarakat jasa konstruksi pada penerapan e-procurement di Lhokseumawe adalah $88,8 \%$.
\end{abstract}

Kata Kunci : e-procurement, Pengadaan barang dan jasa pemerintah secara elektronik

\section{Pendahuluan}

\subsection{Latar Belakang}

Pengadaan barang/jasa pemerintah yang efisien dan efektif merupakan salah satu bagian yang penting dalam perbaikan pengelolaan keuangan negara. Salah satu perwujudannya adalah dengan pelaksanaan proses pengadaan barang/jasa pemerintah secara elektronik (electronic government procurement atau PPE), yaitu dengan memanfaatkan fasilitas teknologi komunikasi dan informasi. Proses pengadaan barang/jasa pemerintah secara elektronik ini akan lebih meningkatkan dan menjamin terjadinya efisiensi, efektifitas, transparansi, dan akuntabilitas dalam pembelanjaan uang negara. Selain itu, proses pengadaan barang/jasa pemerintah secara elektronik ini juga dapat lebih menjamin tersedianya informasi, kesempatan usaha, serta mendorong terjadinya persaingan yang sehat dan terwujudnya keadilan (non discriminative) bagi seluruh pelaku usaha yang 
bergerak di bidang pengadaan barang/jasa pemerintah. Dengan menerapkan $e$ procurement, diharapkan dapat mengurangi dan mengatasi permasalahan yang biasanya timbul dalam pengadaan barang dan jasa. Namun untuk menerapkan sesuatu hal yang baru tidaklah mudah. Diperlukan kemampuan dan kemauan dalam penerapannya. Pihak-pihak yang akan menjadi objek penelitian adalah Owner, Kontraktor, Konsultan, Asosiasi Perusahaan dan Akademisi

\subsection{Tujuan Penelitian}

Berdasarkan latar belakang maka yang menjadi tujuan dari penelitian ini adalah untuk:

1. Mengetahui faktor-faktor apa saja yang akan membuat e-procurement maju dan berkembang di Lhokseumawe;

2. Mengetahui kesiapan masyarakat jasa konstruksi dan Pemerintah Kota Lhokseumawe serta pihak terkait dalam menerapkan e-procurement pada penyediaan jasa konstruksi bagi pembangunan infrastruktur di Lhokseumawe.

\subsection{Manfaat Penelitian}

Dengan diadakannya studi tentang tingkat kesiapan masyarakat jasa konstruksi di Lhokseumawe, diharapkan dapat memberi manfaat antara lain:

1. Hasil penelitian ini dapat memberikan masukan terkait arah pengembangan usaha jasa konstruksi di Lhokseumawe khususnya dan Provinsi NAD umumnya dalam upaya penerapan e-procurement;

2. Hasil penelitian ini dapat memberi landasan yang lebih kuat dan mendorong pemerintah untuk mengkaji kelayakan penyusunan regulasi bagi pengaplikasian e-procurement pada pelaksanaan pembangunan infrastruktur di Lhokseumawe;

\section{Tinjauan Kepustakaan}

\subsection{Peraturan Pemerintah tentang pelaksanan e-procurement}

Dalam hal penyediaan jasa konstruksi, Pemerintah Indonesia telah menerbitkan sebuah keputusan yang memaparkan peraturan pemerintah terkait dengan penyediaan jasa konstruksi. Penerapan dari peraturan ini ditujukan untuk menjamin proses tender terhindar dari korupsi pada Instansi Pemerintah sehingga kondisi persaingan bisnis yang sehat akan muncul. Peraturan tersebut tertuang dalam Keppres No. 80 tahun 2003. Keppres No. 80 tahun 2003 tersebut telah diubah sebanyak tujuh kali dengan perubaan sebagai berikut: Keppres 61 tahun 2004 (perubahan pertama) Perpres 32 tahun 2005 (perubahan kedua) Perpres 70 tahun 2005 (perubahan ketiga) Perpres 8 tahun 2006 (perubahan keempat) Perpres 79 tahun 2006 (perubahan kelima) Perpres 85 tahun 2006 (perubahan keenam) Perpres 95 tahun 2006 (perubahan ketujuh). Pada tahun 2010 dikeluarkan Perpres No. 54 tahun 2010 yang menerangkan tentang e-procurement.

\subsection{Kesiapan Dari Pemerintah Daerah}

Menurut hasil kajian dan riset dari Harvard JFK School of Government dalam Indrajit (2006:15), untuk menerapkan konsep-konsep digitalisasi pada sektor publik, ada beberapa indikator kesiapan yang harus dimiliki dan diperhatikan sungguh-sungguh. Masing-masing elemen tersebut adalah : 
a. Support

Elemen pertama dan paling krusial yang harus dimiliki oleh pemerintah adalah keinginan (intent) dari berbagai kalangan pejabat publik dan politik untuk benar-benar menerapkan konsep e-procurement. Tanpa adanya unsur "political will", maka mustahil berbagai inisiatif pembangunan dan pengembangan e-procurement akan dapat berjalan dengan mulus.

b. Capacity

Yang dimaksud dengan elemen kedua ini adalah adanya unsur kemampuan atau keberdayaan dari pemerintah setempat dalam mewujudkan e-procurement. Yang harus dimiliki oleh pemerintah sehubungan dengan elemen ini, yaitu:

1. Ketersediaan infrastruktur teknologi informasi yang memadai;

2. Ketersediaan sumber daya manusia yang memiliki kompetensi dan keahlian yang dibutuhkan agar penerapan e-procurement dapat sesuai dengan asas manfaat yang diharapkan;

3. Dibentuknya suatu organisasi yang secara khusus menangani sistem $e$ procurement.

\subsection{Kesiapan Dari Pihak Bisnis}

Dalam menjalankan e-procurement juga penting untuk memperhatikan kepentingan dari pihak bisnis sendiri sebagai rekanan lelang. Pihak bisnis sebagai rekanan lelang juga harus memiliki kesiapan agar pelaksanaan penyediaan jasa konstruksi/jasa berjalan sesuai dengan prinsip-prinsip yang diharapkan dalam good corporate governance (GCG) itu sendiri. Salah satu yang perlu mendapatkan perhatian dari pihak bisnis adalah adanya etika bisnis (code of conduct). Dengan memiliki etika bisnis maka kecurangan-kecurangan dan indikasi untuk melakukan berbagai tindakan yang mengarah pada KKN akan dapat dihindarkan. Asosiasi juga harus berperan sebagai penyambung lidah pemerintah untuk mensosialisasikan peraturan dan kebijakan yang berkaitan dengan kegiatan penyediaan jasa konstruksi/jasa pemerintah. Sehingga rekanan lelang yang telah menjadi bagian dari asosiasi, benar-benar memahami apa yang menjadi prosedur dan metode pelelangan yang mereka ikuti.

\subsection{Indikator Kesiapan Dari Sisi Masyarakat}

Sebagai pihak penyelaras akhir dalam e-procurement, tidak ketinggalan juga diperlukan kesiapan dari masyarakat sendiri untuk dapat menunjukkan bahwa program ini telah siap untuk dijalankan. Untuk itu dari diri masyarakat juga harus tumbuh partisipasi aktif berupa keterlibatan secara terbuka (inclusion) dan keikutsertaan (involvement) untuk menerapkan e-procurement. Beberapa indikator yang menunjukan adanya kesiapan tersebut yaitu:

1. Tingkat melek internet dari masyarakat (e-literacy). Dimana masyarakat sebagai salah satu stakeholder dalam penentu kebijakan haruslah memahami berbagai informasi yang bisa mereka dapatkan dari penggunaan internet.

2. Penyediaan jasa konstruksi secara online (e-procurement) juga membutuhkan peranan besar Lembaga Swadaya Masyarakat (LSM) yang memiliki perhatian yang besar terhadap perkembangan teknologi informasi dan kegiatan penyediaan jasa konstruksi/jasa pemerintah.

3. Adanya lembaga pendidikan yang terkait di bidang teknologi informasi. 
4. Adanya kesediaan dari masyarakat untuk melakukan pengaduan kepada pihak yang berwenang terhadap penyediaan jasa konstruksi/jasa yang tidak sesuai dengan ketentuan yang berlaku dan terindikasi terdapat unsur KKN.

\subsection{Validitas dan Reliabilitas}

Menurut Azwar (1986) para ahli psikometri telah menetapkan kriteria bagi suatu alat ukur psikologis untuk dapat dinyatakan sebagai alat ukur yang baik dan mampu memberikan informasi yang tidak menyesatkan. Kriteria itu antara lain adalah valid, reliabel, norma dan praktis. Sifat reliabel dan valid diperlihatkan oleh tingginya reliabilitas dan validitas hasil ukur suatu tes. Suatu alat ukur yang tidak reliabel atau tidak valid akan memberikan informasi yang keliru mengenai keadaan subjek atau individu yang dikenai tes itu.

\subsubsection{Validitas}

Sugiyono (2006) menyatakan bahwa uji validitas merupakan suatu langkah pengujian yang dilakukan terhadap isi (content) dari suatu instrumen, dengan tujuan untuk mengukur ketepatan instrumen yang digunakan dalam suatu penelitian. Instrumen yang valid berarti alat ukur yang digunakan untuk mendapatkan data valid. Valid berarti instrumen tersebut dapat digunakan untuk mengukur apa yang hendak diukur.

Dalam penelitian ini, dengan jumlah reponden sebanyak 30 orang, bila koefisien korelasi lebih besar daripada nilai standar 0,36 maka suatu pernyataan tersebut valid, sebaliknya jika koefisien korelasi lebih kecil daripada nilai standar 0,36 maka suatu pernyataan dinyatakan tidak valid. Analisis validitas dilakukan dengan menggunakan Program Microsoft Excel 2007.

\subsubsection{Reliabilitas}

Menurut Husaini (2003) Uji reliabilitas adalah proses pengukuran terhadap ketepatan (konsisten) dari suatu instrumen. Pengujian ini dimaksudkan untuk menjamin instrumen yang digunakan merupakan sebuah instrumen yang handal, konsistensi, stabil dan dependibalitas, sehingga bila digunakan berkali-kali akan menghasilkan data yang sama. Untuk koefisien reliabilitas diketahui dari besarnya koefisien alpha.

\section{Metodologi Penelitian}

\subsection{Lokasi Penelitian}

Penelitian ini dilaksanakan di Kota Lhokseumawe Provinsi Nanggroe Aceh Darussalam.

\subsection{Metode Pengumpulan Data}

Metode pengumpulan data dilakukan dengan survei literatur, yaitu pencarian data-data yang berhubungan dengan penerapan e-procurement di Nanggroe Aceh Darussalam, khususnya di daerah Kota Lhokseumawe. Pengumpulan data juga dilakukan dengan wawancara dengan pihak-pihak yang akan mengimplementasikan e-procurement dalam penyediaan jasa konstruksi. Untuk mendukung perolehan data, maka penulis menyebarkan kuesioner yang 
ditujukan kepada orang dan Instansi yang dianggap memiliki wewenang dan kemampuan untuk menerapkan e-procurement dalam mendapatkan barang dan jasa. Data yang diperlukan untuk analisis ini adalah responden sebanyak 30 sampel, jawaban responden berbentuk skala likert dengan rincian skalanya adalah dari tingkatan paling positif hingga negatif, seperti skala 1 (sangat tidak setuju), skala 2 (tidak setuju), skala 3 (cukup setuju), skala 4 (setuju), dan skala 5 (sangat setuju).

\subsection{Data Primer}

Data primer adalah data yang diperoleh dari hasil pengolahan kuesioner yang telah diberikan kepada responden dan diisi. Pertanyaan kuesioner yang diajukan ini bertujuan untuk mengetahui tingkat kesiapan penerapan $e$ procurement dari pihak terkait di Lhokseumawe, serta untuk mengetahui apa saja kendala yang terjadi ketika menerapkan e-procurement dalam penyediaan jasa konstruksi.

\subsection{Data Sekunder}

Data sekunder adalah data yang diperoleh dari hasil survei literatur, yaitu data yang berkaitan dengan e-procurement seperti definisi dan pengetahuan tentang e-procurement. Sedangkan data tentang praktek e-procurement adalah data dokumen lelang yang dilakukan oleh BRR NAD Nias dan Pemerintah Aceh, serta penelitian-penelitian relevan baik didalam dan luar negeri yang telah dipublikasikan.

\subsection{Responden}

Responden dari penelitian ini adalah para owner, konsultan, kontraktor, akademisi dan asosiasi perusahaan yang ada di Lhokseumawe dengan jumlah 30 orang. Direncanakan konsultan, kontraktor, asosiasi perusahaan dan akademisi masing-masing 5 (lima) orang dan jumlah owner 10 (sepuluh) orang.

\subsection{Skala Likert}

Untuk mengukur variabel penelitian digunakan skala Likert, dimana variabel yang akan diukur dijabarkan menjadi beberapa level variabel. Bentuk setiap pertanyaan atau dukungan sikap diungkapkan dari sangat baik sampai sangat tidak baik, dengan skor 1 sampai 5, dimana :

\section{Analisis dan Pengolahan Data}

\subsection{Analisis Validitas}

Dalam uji penelitian ini, uji validitas item-item pernyataan-pernyataan dalam kuesioner dilakukan dengan menghitung koefisien korelasi produk moment dari tiap-tiap item pertanyaan dengan skor total yang diperoleh. Koefisien korelasi masing-masing item kemudian dibandingkan dengan nilai kritis $r$, yang dapat diliat pada tabel product moment yang tersedia dengan derajat kebebasannya dan signifikansinya. Bila koefisien korelasi lebih besar daripada nilai standar 0,3 maka suatu pertanyaan tersebut valid, sebaliknya jika koefisien korelasi lebih kecil atau kurang dari 0,3 maka menunjukan tidak adanya konsistensi jawaban responden. Pengolahan data untuk memperolah nilai valid tidaknya item pertanyaan dilakukan dengan menggunakan aplikasi Microsoft Excel. 


\subsection{Analisis Reliabilitas}

Analisis Reliabilitas menunjuk pada suatu pengertian bahwa suatu instrument dapat dipercaya untuk digunakan sebagai alat pengumpul data (Arikunto:2002). Umumnya, analisis reliabilitas yang digunakan adalah analisis Cronbach Alpha. Dalam penggunaan analisis ini maka koefisien Cronbach Alpha harus lebih besar atau sama dengan 0.60 dengan tingkat keakuratan 95\% pada responden dengan jumlah 30 orang, yaitu nilai yang dianggap dapat menguji reliabel tidaknya kuesioner yang digunakan.

Hasil perhitungan reliabilitas dari variabel tingkat kesiapan masyarakat jasa konstruksi dalam penerapan e-procurement di Lhokseumawe berdasarkan jawaban responden yang menggunakan bentuk penilaian skala likert dapat dilihat pada Tabel 1 dibawah ini:

Tabel 1 Hasil perhitungan Reliabilitas

\begin{tabular}{|l|c|c|c|}
\hline \multicolumn{1}{|c|}{ Faktor } & $\begin{array}{c}\text { Nilai Alpha } \\
\text { yang didapat }\end{array}$ & $\begin{array}{c}\text { Koefisien } \\
\text { Alpha }\end{array}$ & $\begin{array}{c}\text { Jumlah } \\
\text { variabel }\end{array}$ \\
\hline $\begin{array}{l}\text { Tingkat kesiapan masyarakat jasa } \\
\text { konstruksi terhadap penerapan } \\
\text { e-procurement di Lhokseumawe }\end{array}$ & 0,862 & 0,60 & 20 \\
\hline
\end{tabular}

\subsection{Tingkat Kesiapan Masyarakat Jasa Konstruksi}

\subsubsection{Kelompok Responden Owner}

Jawaban kuesioner dari kelompok responden Owner dapat dilihat pada histogram berikut:

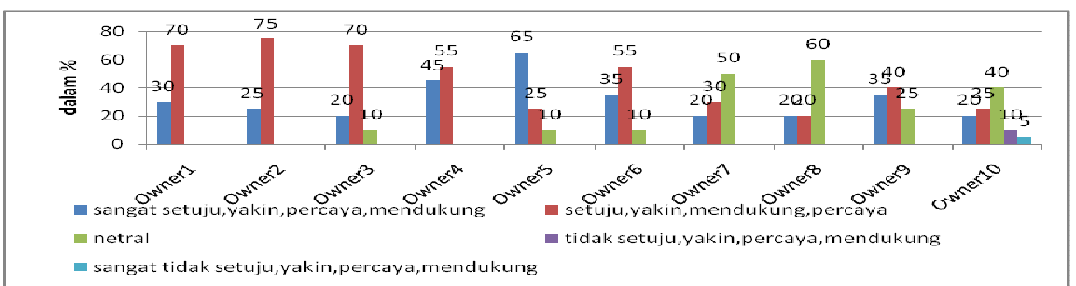

Gambar 1 Grafik persentase tingkat kesiapan kelompok responden Owner

\subsubsection{Kelompok Responden Kontraktor}

Jawaban kuesioner dari kelompok responden kontraktor dapat dilihat pada histogram berikut:

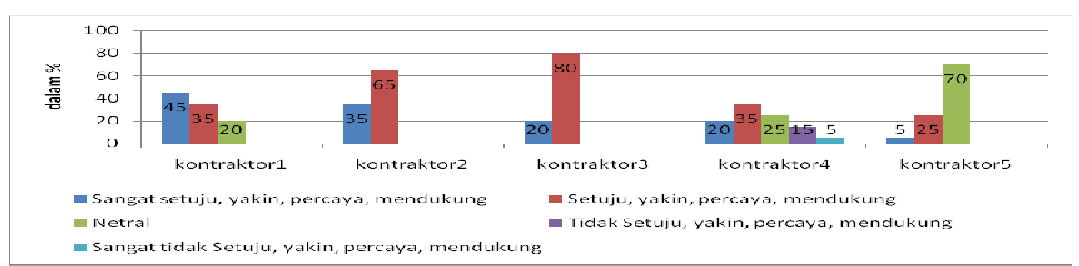

Gambar 2 Grafik persentase tingkat kesiapan responden Kontraktor

\subsubsection{Kelompok Responden Konsultan}

Jawaban kuesioner dari kelompok responden konsultan dapat dilihat pada histogram berikut: 


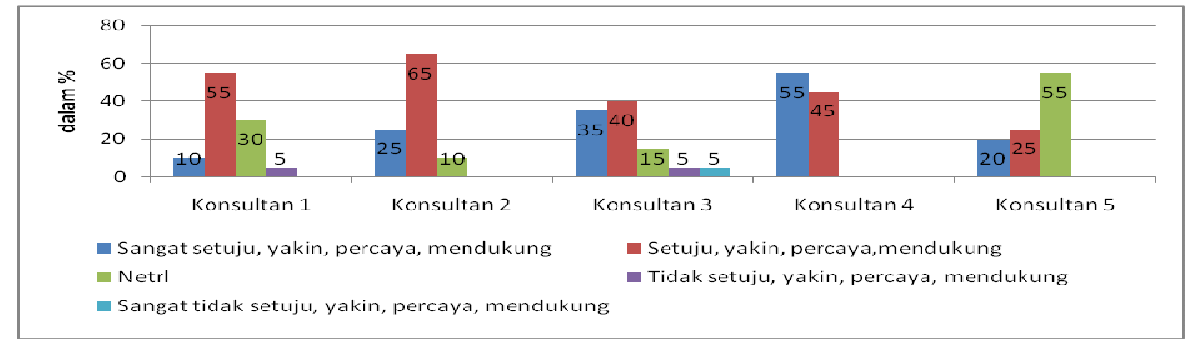

Gambar 3 Grafik persentase tingkat kesiapan responden Konsultan

\subsubsection{Kelompok Responden Asosiasi Perusahaan}

Jawaban kuesioner dari kelompok responden Asosiasi Perusahaan dapat dilihat pada histogram berikut:

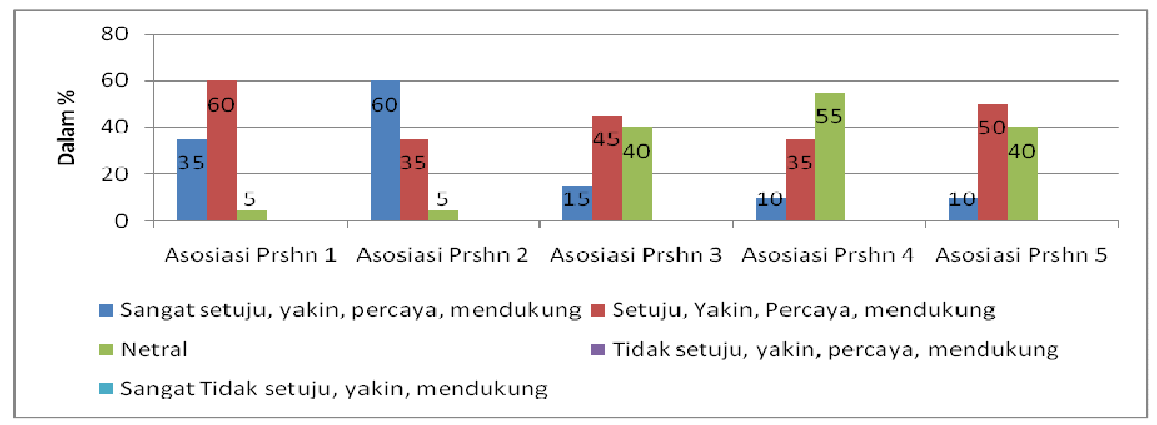

\section{Gambar 4 Grafik persentase tingkat kesiapan responden Asosiasi Perusahaan}

\subsubsection{Kelompok Responden Akademisi}

Jawaban kuesioner dari kelompok responden Akedemisi dapat dilihat pada histogram berikut:

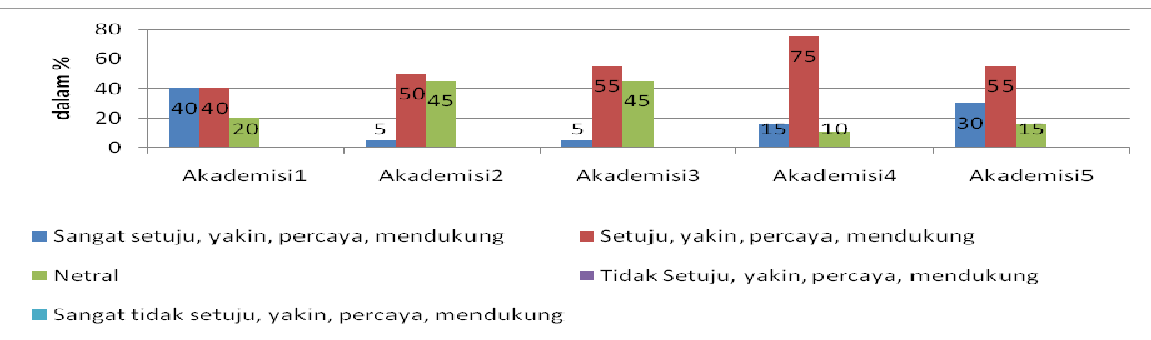

Gambar 5 Grafik persentase tingkat kesiapan responden Akademisi

\subsection{Deskripsi Tingkat Kesiapan Masyarakat Jasa Konstruksi Terhadap Penerapan E-Procurement Berdasarkan Kelompok Responden}

\subsubsection{Tingkat kesiapan Owner dalam menerapkan e-procurement}

Berdasarkan perhitungan yang telah dilakukan terhadap hasil kuesioner yang telah disebarkan kepada responden maka dapat disimpulkan bahwa sebagian besar owner mempunyai komitmen yang kuat dan akan berusaha untuk menjalankan e-procurement dengan baik, meningkatkan kemampuan mereka dalam menerapkan e-procurement di Lhokseumawe. Secara umum dapat digeneralisaasikan bahwa tingkat kesiapan Owner dalam kesiapan menerapkan e-procurement adalah sebesar $78 \%$. 


\subsubsection{Tingkat kesiapan Kontraktor dalam menerapkan e-procurement}

Berdasarkan perhitungan yang telah dilakukan terhadap hasil kuesioner yang telah disebarkan kepada responden maka dapat disimpulkan bahwa sebagian besar owner mempunyai komitmen yang kuat dan akan berusaha untuk menjalankan e-procurement dengan baik, meningkatkan kemampuan dalam menerapkan e-procurement. Secara umum dapat digeneralisaasikan bahwa tingkat kesiapan kontraktor dalam kesiapan menerapkan e-procurement sebesar $73 \%$.

\subsubsection{Tingkat kesiapan Konsultan dalam menerapkan e-procurement}

Berdasarkan perhitungan yang telah dilakukan terhadap hasil kuesioner yang telah disebarkan kepada responden maka dapat disimpulkan bahwa sebagian besar owner mempunyai komitmen yang kuat dan akan berusaha untuk menjalankan e-procurement dengan baik, meningkatkan kemampuan dalam menerapkan e-procurement. Secara umum dapat digeneralisaasikan bahwa tingkat kesiapan konsultan dalam kesiapan menerapkan e-procurement sebesar $75 \%$

\subsubsection{Tingkat Kesiapan Asosiasi Perusahaan dalam menerapkan e-procurement}

Berdasarkan perhitungan yang telah dilakukan terhadap hasil kuesioner yang telah disebarkan kepada responden maka dapat disimpulkan bahwa sebagian besar owner mempunyai komitmen yang kuat dan akan berusaha untuk menjalankan e-procurement dengan baik, meningkatkan kemampuan dalam menerapkan e-procurement. Secara umum dapat digeneralisaasikan bahwa tingkat kesiapan asosiasi perusahaan dalam kesiapan menerapkan e-procurement adalah sebesar $71 \%$.

\subsubsection{Tingkat Kesiapan Akademisi dalam menerapkan e-procurement}

Berdasarkan perhitungan yang telah dilakukan terhadap hasil kuesioner yang telah disebarkan kepada responden maka dapat disimpulkan bahwa sebagian besar owner mempunyai komitmen yang kuat dan akan berusaha untuk menjalankan e-procurement dengan baik, meningkatkan kemampuan dalam menerapkan e-procurement. Secara umum dapat digeneralisaasikan bahwa tingkat kesiapan asosiasi perusahaan dalam kesiapan menerapkan e-procurement adalah sebesar $73 \%$. Apabila masing-masing tingkat kesiapan itu digabungkan maka didapatkan nilai tingkat kesiapan seluruh jumlah responden yaitu sebesar $74 \%$. Artinya tingkat kesiapan masyarakat jasa konstruksi dalam upaya penerapan $e$ procurement di Lhokseumawe adalah sebesar $74 \%$.

\section{Kesimpulan} berikut :

Berdasarkan hasil penelitian maka kesimpulan dapat diuraikan sebagai

1. Owner, kontraktor, konsultan, asosiasi perusahaan dan akademisi umumnya setuju apabila e-procurement diterapkan di Lhokseumawe. Namun ada beberapa responden yang menyatakan keberatan apabila e-procurement diwajibkan bagi seluruh masyarakat jasa konstruksi dalan pengadaan barang dan jasa.

2. Penggunaan kuesioner sebagai alat penelitian dinyatakan layak dengan mengacu pada nilai-nilai yang diperoleh terhadap variabel-variabel tingkat 
kesiapan masyarakat jasa konstruksi terhadap penerapan e-procurement di Lhokseumawe berada di atas nilai Cronbach Alpha adalah 0,60 yaitu memiliki nilai alpha sebesar 0,862 dan hasil uji validitas kuesioner sebesar 14 item dari 20 item memiliki nilai diatas nilai $r$ tabel, yaitu nilainya diatas 0,361 .

3. Mean tertinggi dari variabel tingkat kesiapan masyarakat jasa konstruksi terhadap penerapan e-procurement diLhokseumawe dengan nilai 4,47 yang berarti deskripsi ini dipahami dan disetujui oleh responden. Mean terendah dengan nilai 3,63 menunjukan bahwa deskripsi ini juga dipahami dan disetujui oleh responden.

4. Frekuensi tertinggi dari variabel tingkat kesiapan masyarakat jasa konstruksi terhadap penerapan e-procurement diLhokseumawe adalah mengenai dukungan para pemimpin perusahaan bagi perusahaan untuk mendukung penerapan e-procurement di Lhokseumawe yaitu sebesar $89,33 \%$

\section{Daftar Kepustakaan}

1. Eko Indrajit, Richardus \& Richardus Djokopranoto, 2003, Dasar, Prinsip, Teknik, Dan Potensi Pengembangan E-procurement, Grasindo, Jakarta.

2. Eric Choen Weng Lou \& Alshawi, 2009, Critical Success Factors for Etendering

3. Florence Gokmauli L, 2008, Kajian Kelayakan Pelaksanaan Sistem Lelang Elektronik (E-procurement) Pada Instansi Pemerintah Ditinjau Dari Prasyarat Pelaksanaan, FT UI, Jakarta.

4. Narbuko, C. Dan achmadi, A., 2004, Metodologi Penelitian, Bumi Aksara, Jakarta.

5. Riduwan, 2002, Skala Pengukuran Variabel-Variabel Penelitian, Alfabeta, Bandung.

6. Riduwan, 2003, Dasar-dasar Statistika, Alfabeta, Bandung.

7. Risawan Bentara, 2010, Modul Sosialisasi Penerapan E-procurement di Aceh Utara, Risben, Lhokseumawe.

8. Sugiyono, 2003, Metode Penelitian Bisnis, Penerbit CV. Alfabeta, Bandung.

9. Soekirno, Purnomo, 2005, Prakualifikasi, Lelang \& Kontrak Konstruksi, FT UI, Bandung. 